\title{
ASSESSING THE IMPACT OF PROTECTIONISM UPON THE PERFORMANCE OF ACTORS The Case of the French and Korean Film Industries
}

\author{
Hee Jun Kim \\ Arts Republic, Korea and BH Paris Media Production, France \\ heejun9522@gmail.com
}

\author{
Maxime Martigane \\ L'Entrée des Artistes Olivier Belmondo \\ martinmaxime5518@yahoo.fr
}

\author{
Jimmyn Parc \\ Seoul National University and Sciences Po Paris \\ jimmynparc@gmail.com
}

\begin{abstract}
The film industry has received increasing attention due to social, cultural, and economic reasons. Consequently, many countries have introduced various measures to protect and promote it, particularly through the use of subsidies. So far, many works have focused on how protectionism affects the film industry with focus on production and consumption. In this regard, this paper focuses on the impact of protectionism upon the performance of actors by comparing the French and Korean film industries, which has been less studied. This paper reveals three interesting points that should be carefully considered in order to make effective policies for the film industry. First, subsidies to protect the film industry increase the performance fee of actors since part of the subsidies goes to them. Second, direct subsidies that are distributed to the director also distort the film producing structure by increasing the number of actor-directors. Third, subsidies for international co-production increase the number of actors who collaborate with international producers.
\end{abstract}

\section{Keywords}

acting; actor-director; film industry; film policy; international co-production; overseas expansion; performance fee; subsidy 


\section{About the Authors}

Hee Jun Kim is an actor at Arts Republic, Korea and at BH Paris Media Production, France. He is a former lecturer at Paekche Institute of the Arts, Korea. He is the president of P\&H Studio and a member of the Korean Actors Association. He has appeared in numerous films, theatrical plays, and TV dramas both in Korea and France. Recently, he took on the role of Michael in Othello: Jealousy is My Force through October and November 2017 at the National Theater of Korea. Currently, he resides in Paris, France for various performance activities.

Maxime Martigane is an actor-director and photographer. He is also a professor at L'Entrée des Artistes Olivier Belmondo, France. He has directed a number of short films and also acted in them. Some of his representative works are I dance in my dream (2018), La double consciences (2018), Je suis le jeu du cadeau (2018), Aristide (2018), 180 degrés (2017), H Game (2015), and Une petite étoile filante (2015).

Jimmyn Parc is a visiting lecturer at the Institut d'études politiques de Paris (Sciences Po), France and a research associate at the EU Centre, Graduate School of International Studies, Seoul National University in Korea. He is also a Research Associate of the European Centre for International Political Economy (ECIPE), in Brussels, Belgium. He has published numerous academic articles and conducted a number of research projects related to the competitiveness of organizations, industries, and countries. For his main topic of research on the cultural and creative service industries, Dr. Parc uses historical and comparative approaches to further understand their international business strategies. In particular, he focuses on the film and music industries which are faced with a changing business and trade environment as well as new challenges from digitization. 
It is often believed that national culture is unique and special, thus it needs to be carefully protected, a point that has been advocated in the Convention for the Protection and Promotion of the Diversity of Cultural Expressions supported by UNESCO. Among the various cultural industries, the film industry is one of the largest and can have significant social, political, and even economic impact. As a result, politicians and governments from all political persuasions have sought to exploit films as a way to promote their national brand and have even on occasion used it as propaganda. For example, it is widely known that the Nazis used film production as a propaganda tool and even featured Adolf Hitler himself in a series of films ("Leni Riefenstahl"; Rentschler). In the same manner, the United States produced a significant number of propaganda films during the two World Wars in order to sway neutral opinion, manipulate public sentiment, and influence the behavior of its citizens (Wood and Culbert; Suid and Culbert). More recently, the economic potential of the industry has been further highlighted.

For these reasons, a number of governments around the world have sought to intervene greatly in their film industries as a way to promote their activities. In particular, when facing the market dominance of Hollywood films, many countries have felt the need to protect their film industries through subsidies and various other protectionist measures. However, a number of studies produced describe how such protectionist measures are in fact detrimental to the film industry (Kornai; Messerlin and Parc, "The Effect of Screen Quotas," "The Real Impact of Subsidies"; Messerlin and Vanderschelden; Parc, "Evaluating the Effects," "The Effects of Protection"). Their approaches are supported by rigorous analyses based on statistical data and business activities. In contrast to the general perception, the conclusion of these studies is that such national policies have led to a deterioration in the business and economic aspects of the film industry as well as the quality of films. Naturally, as an actor, a director, and an academic, we would like to examine the impact of these protectionist measures on the performance of actors, which has not been explored in depth, particularly in a comparative way between France and Korea.

Although evaluating the impact of protectionism on the actor's performance is an important subject when assessing film policies, it can be very hard to define this concept and compare them in just one paper. Furthermore, its definition varies depending on each, school, country, or even on one's personal experience. In this regard, undertaking an effort to compare directly the performances of French and Korean actors without any formulaic framework would be a questionable approach and certainly far too subjective. Instead, this paper seeks to examine the evolution in the performance of actors with a focus on positional relationships with the director, their fees, and overseas expansion. This approach has been chosen because the 
level of actor-director positional relations, actors' fee, and their overseas expansion are all closely related to a successful onscreen performance.

The organization of this paper has been structured in order to address these issues efficiently. As such, the first section briefly explains the protectionist measures that France and Korea have adopted to support their film industries. The second section explores how French and Korean actors evolved domestically when facing protectionist measures, such as the "coalition" between directors and actors and its impact on actor's performance fees. The third section examines the overseas expansion of actors and its implications on protectionism. Lastly, the concluding section summarizes the main points to be drawn from this analysis. Since we, the authors of this paper, are composed of an actor, an actor-director, and an academic respectively, and given that this paper is rather exploratory, this resulting work is rather descriptive as it is based on our experiences in France and Korea. Furthermore, this subject matter has been rarely documented elsewhere. However, its discussion opens up new perspectives on studies of the film industry.

\section{PROTECTIONIST MEASURES IN FRANCE AND KOREA}

\section{France's Protectionist Measures ${ }^{1}$}

Import quotas were adopted in France during the early 1920s. However, these measures soon became ineffective because although the number of domestic movie theaters increased, the supply of French films was not enough. Furthermore, the industry faced strong pressure from the US government to abolish the system (Hayward; Messerlin and Vanderschelden). In another development, American subsidiaries were established by the Hollywood studios in France, which were treated essentially as French companies (Gubak). Later, in the early 1930s, with the appearance of sound films, dubbing quotas were introduced in order to restrict the number of films in foreign languages, notably Hollywood films. As a result, it is notable that while there were 150 foreign-language films in 1936, there were only 110 in 1952 (Hayward). This system continues to this day. Screen quotas have been in operation since 1946 and were further strengthened in 1948 due to the BlumByrnes Agreements. ${ }^{2}$ However, the recourse to subsidies as the main instrument of protection for the French film industry since the 1950 os makes these screen quotas obsolete, as underlined by a study from the Motion Picture Association of America (MPAA). 
After World War II, the French government began to provide its film industry with an abundant amount of subsidies in order to increase the number of films produced in France. Under these conditions, the number of domestic films released was significantly increased. Since 1953, the French government began to automatically subsidize films produced by experienced directors, but not debut directors. To meet the "experienced" criteria, the director simply had to have already produced a film regardless of the length, e.g., short or full length. There have also been selective subsidies since 1959. These subsidies are for film proposals that have passed a "quality test" which verifies whether the film is cultural and/ or has notable French contents. Interestingly, the range of beneficiaries for these subsidies have progressively expanded to distributors in 1960 and to actor-directors in 1963. However, due to the ineffectiveness of these subsidies, they are now limited to films that are shot mostly in the French language.

Throughout its history, the French subsidy system has faced various problems. The automatic application of subsidies has largely been misused by domestic and foreign film studios as well as individuals. Furthermore, these subsidies are prorated according to past achievements at the box office; therefore, most are provided to well-established directors who have already produced successful films at the box office. The amount of selective subsidies, on the other hand, are usually decided by the Centre National du Cinéma et de l'Image Animée (CNC), an administrative arm of the French Ministry of Culture, which is responsible for the production and promotion of cinematic and audiovisual arts in France. One prominent criticism of this practice is that only a few big-budget films benefit from these selective subsidies (Cocq; Messerlin and Cocq). Despite its huge amount, Messerlin and Parc conclude that the French subsidy regime has not been effective enough to promote the French film industry ("The Real Impact of Subsidies").

\section{Korea's Protectionist Measures ${ }^{3}$}

In contrast to France, the Korean film industry has utilized all three distinctive protectionist measures, which includes import quotas, screen quotas, and subsidies. Interestingly, Korea employed each measure for a specific period; hence, the impact of these different protectionist measures can be clearly seen throughout the history of its film industry (Parc, "L'Impact du Quota de Diffusion," "Evaluating the Effects," "The Effects of Protection"). For example, import quotas were applied to the Korean film industry from 1958 to 1986. Since then, the screen quota system has been the most visible element of Korea's policy. However, following the 2006 Korea-US Free Trade Agreement, the system was cut by half to 73 days from 146 days. The subsidies, meanwhile, stayed very modest until the late 1990 (Kim). 
However, from the mid-2ooos, they have been substantially increased, notably since the introduction of the seat tax, which is based on a three-percent charge on each ticket (Parc, "Evaluating the Effects").

These measures were initially introduced in order to protect and promote the Korean film industry; however, they have in fact brought about unintended results. The import quotas sought to control the number of foreign films while increasing the number of domestic films produced. Contrary to their expectation, the import quotas caused a serious deterioration in the quality of domestic films and decreased the overall size of the film market which includes both foreign and domestic films (for details, see Parc's “The Effects of Protection"). Screen quotas were often believed to be the savior of the Korean film industry since they set the number of days for showing Korean films while limiting the number of days for foreign films. Unfortunately, the reality is that it does not ensure increased admissions to domestic films during these screening days. Rather, it simply guarantees these Korean films to have some "potential market access" to movie theaters. Hence, without any enhanced quality of the films, it is hard to see how screen quotas, in themselves, can promote the film industry.

By contrast, the Korean film industry has received few subsidies because the industry had long been considered as having little economic impact, although a law had been legislated in the 1960 os for government subsidies to support the film industry. In the late 1990s, however, the government changed its view of the film industry and began to provide it with subsidies. In particular, after the mid-2ooos, the level of subsidies was increased considerably compared to that of the preceding years. Due to this development, many Korean cineastes have come to believe that the increased subsidies helped with the emergence of the Korean film industry, beginning in the late 1990s. However, in reality, the emergence of the industry began before increased subsidies were provided and in fact should be credited to the provision of private funds (Messerlin and Parc, "Evaluating the Effects," "The Effects of Protection"). Specifically, these came from large Korean conglomerates who redirected their initial investments in Hollywood to Korea in the early 1990 os (Parc, "Evaluating the Effects," "The Effects of Protection").

In order to establish a source for subsidies, the seat tax was introduced in 2007. It is noteworthy to mention here that securing the pool of subsidies should be distinguished from the actual amount that is spent on the industry. Furthermore, when the amount of subsidies between France and Korea is compared, the amount of Korean subsidies is more modest, but the Korean film industry has performed better. This raises an interesting question about the impact of protectionism on the performance of actors, which this paper examines. 


\section{THE IMPACT OF PROTECTIONIST MEASURES ON DIRECTOR-ACTOR POSITIONAL RELATIONS AND INCOME}

In general, there is a basic assumption that all directors, actors, and crew members do their best to produce quality films, which is in turn a common goal that can attract a positive response from the audience, society, and critics. In order to achieve this goal, various means are available such as securing a large budget, developing an interesting plot/scenario, recruiting a quality director, casting popular actors, hiring competent crew members, maintaining effective distribution networks, establishing a post-screening plan for the home entertainment market, and linking the film with overseas sales. However, our focus is on actors who operate under protectionist measures, notably government subsidies. Hence, we will examine how the positional relationship between the director and the actor, as well as the actor's performance fee, have been affected by the protectionist measures in France and Korea.

\section{Director-Actor Positional Relationship}

The positional relationship between the director and actor is considered to be an important factor toward a successful theater performance (McLaughlin and Black). Thus, this is also the case for a film production. In order to achieve such a goal, there are two options when the positional relationship is considered. The first option is for there to be more specialization between the roles of director and actor, making the roles of director and actor separate. In this case, strong chemistry is needed between the director and actors. The common approach for this option is the notion of acteur fétiche or "preferred actors." In contrast, the second option is for one person to be both actor and director, which means that they can pursue interests from the perspective of both sides, in other words as an actor-director. Interestingly, these two options have occurred throughout the history of both the French and Korean film industries, whether they received government subsidies or not. In order to produce quality films, directors generally explore different filmmaking methods in order to find the most suitable one, regardless of the available subsidy and its amount. Hence, in theory, these two options can appear randomly at any time.

From the 1960 s to the 1990 , when subsidies were not provided to the Korean film industry, the first option, the collaboration between a director and his or her favored actors, was often used regardless of what situation the Korean film industry was in. For instance, in the 1960s, when the Korean film industry enjoyed its golden era, Shin Sung-il and Um Aing-ran were two of the top actors at the time. 
They shot many films with a few directors, notably Lee Man-hui, Jung Jin-woo, and Shin Sang-ok. Later in the 1970s, Park No-sik became the preferred actor for several directors. Im Kwon-taek worked with Kim Hyo-cheon, and Bae Chang-ho worked with Ahn Sung-ki for many films in the 1980s. In the 1990s, as Korean films emerged internationally, this kind of collaboration became more visible. In using the first option, these examples can be interpreted as an effort to produce quality films.

The French film industry has shown a similar trend in its early years. Jean-Luc Godard shot many films with Anna Karina, Leos Carax with Denis Lavant, Gérard Oury with Louis de Funès, and Francois Truffaut with Jean-Pierre Leaud. However, this trend began to fade throughout the 1970 s and 1980 os. Instead, the second option of the actor-director replaced the precedent of acteur fétiche and has since become prevalent in the French film industry. Even when compared with other countries, the abundance of actor-directors is quite unique in France. The more interesting point is that despite the abundance of actor-directors, this approach did not lead to much success in the 1970 os and 1980 os followed a previously thriving era of Nouvelle Vague or the New Wave. Of course, there may be other reasons for this lack as well.

If the actor-director approach was not helpful in producing quality films in the 1970 and 1980s, why has it then become so rooted in the French film industry? The answer lies in the country's subsidy regime. Since 1953, the French government began to subsidize the film industry in order to protect it from the dominance of Hollywood films in Europe. Initially, this was provided to producers when they made films; however, following the enactment of two new decrees in June and September 1959, the beneficiaries of this scheme were extended to both production companies in 1960, and author and directors in 1963. More importantly, no subsidies were granted to actors. Hence, the only way that they could benefit from this scheme was through a private contract that guaranteed a performance fee.

After the Nouvelle Vague period, the French film industry became stagnant during the 1970 and 1980 s, when there were few successful films and a decline in profits. Under these negative conditions, a director tended to either work with unknown actors while securing a large portion of the subsidies for himself or herself. Furthermore, he or she could simply take on one of the main acting roles. This is a passive way of overcoming difficulties during a stagnant period. In contrast, during a successful period, the director would choose to work with his or her preferred (or popular) actor in order to produce more appealing films and thus increase the success rate or take a lesser important or marginal role if he or she wishes to play in the film. This is more of an active way to overcome difficulties. Unfortunately, the passive way has dominated the French film industry. In general, actor-directors are automatically paid more regardless of the success of their films. Furthermore, 
the amount of performance fee has always been increased through subsidies while being less affected by the market function. As a result, this has been the principal trend in the French film industry, which has continued without any criticism and has become the routine way of producing films since then.

\section{Performance Fee under Protectionist Measures}

The amount of performance fee depends on popularity, which increases demand in market, in general; the more popular, the higher the performance fee. Such popularity is based on many different variables, for instance appearance, acting quality, and the box office record of previous works. However, these variables are often focused on a limited geographical scope. If we expand the analysis from the domestic to the international in order to compare performance fees, different implications can be drawn. This is because each country has a different market size, which leads to a contrast in the expected sales and can then affect a different performance fee for the actor on average. In this respect, if we compare performance fees internationally, we can clearly see that the size of the market is one of the most important factors.

Such a trend can be seen in the transfer of football players from one league to another. For instance, in recent years, several football clubs in the Chinese Super League have sought to sign several big-name players such as Cristiano Ronaldo and Wayne Rooney, who play in Italy's Serie A and England's Premier League respectively. Although they are two of the highest-paid players, these Chinese football clubs have sought to offer them more than what they can earn in their own league. In terms of level and status, the leagues in Italy and England have a higher reputation than any other, including China. However, the Chinese market is one of the largest in the world with a huge potential for further growth. Thus, although the Chinese League is not as well-known as those in Italy and England, the clubs in the Chinese League are able to offer salaries higher than elsewhere.

According to Messerlin and Parc in "The Real Impact," the French and Korean market sizes were initially similar in the 1970s. Although the Korean film industry experienced long-term stagnancy throughout the 1970 os and 1980s, its market size has recently grown to a similar scale and is now looking to be even larger than that of France (67). Therefore, it can be easily assumed that the average performance fee among French actors was higher than Korea throughout the 1970s and 1980s. Yet, the recent performance fee should not have such a considerable disparity between the two countries, given that they have very similar market sizes. Surely, by expanding the market size through globalization, the performance fee can increase. 
In recent years, Vincent Maraval and Capital have both reported that French actors are paid too much when compared with their counterparts from other countries. It is important to recognize here that the performance fee for French actors consists of two parts: a basic fee based on their performance within the fixed (or expected) market size, and then a "supplementary" fee from government subsidies, which actually constitutes the larger portion. In this regard, Capital pointed out the fact that French actors have benefited from government subsidies which are very large. For example, actors such as Jean Dujardin and Gilles Lellouche have received US\$ 5.4 and 6.6 million respectively in public aid for three films; these include La French, Möbius, and Les Infidèles for Dujardin, and La French, L'Enquête, and Les Infidèles for Lellouche. In brief, government subsidies increase the level of the performance fee for actors. Interestingly, when French actors work outside of France, excluding when it is a co-production which has government subsidies involved, they will receive a much lower performance fee which is essentially "subsidy-free," according to Maraval.

The Korean film industry, on the other hand, is very different from that of France. Although government subsidies in Korea have recently increased compared to previous amounts, it is still more modest when compared with France according to Messerlin and Parc ("The Effect of Screen Quotas" 62). Furthermore, these subsidies were mostly distributed in order to establish supporting infrastructure and distribution channels in the early years ("The Effect of Screen Quotas" 72). Therefore, directors and actors in Korea have not directly benefited from these subsidies as their counterparts have in France. This explains why many Korean actors have recently gone to China or Japan in order to diversify their income sources and to increase their performance fee in the larger markets. Through these two cases, it can be said that government subsidies, which initially aimed to protect and promote the film industry, have in fact resulted in increasing the performance fee for French actors.

\section{THE IMPACT OF PROTECTIONIST MEASURES ON ACTOR'S OVERSEAS EXPANSION}

In the era of globalization, gaining and receiving international recognition is considered to be the highest honor in the film industry. This is why many directors and actors seek to win prizes at internationally well-known film festivals such as Cannes and Venice, as well as many others. Another way of gaining international recognition is to work with prestigious foreign producers. Directors and actors can be invited to produce films in other countries or collaborate with a foreign production. This situation can also change with the introduction of international co-production and its related subsidies. 


\section{Understanding International Co-production}

Co-production evolved as a way to share the financial burden of film production costs, particularly after World War II, when many European countries were in financial distress as they focused on reconstruction efforts in their own countries. This approach began with efforts between France and Italy following the signing of their bilateral co-production agreement in October 1949. This was seen as a good way to increase the number of films produced during a time when competition with Hollywood films had increased in Europe. In order to protect their film industries, European countries throughout the 1950 s and 1960 os began to define "national films" as an economic necessity in the name of international cooperation, and even highlighted the idea of a "European cinema" (Bergfelder). However, many Hollywood studios began to establish their own subsidiaries on the continent, which were then recognized as European companies. As such, the Hollywood studios were able to benefit from the subsidies that were designed to provide support for "European" co-production efforts (Parc, "Understanding Film Co-production Strategies").

As explained in the previous section, many countries subsidized their film industries to protect and promote them, which led to an increase in the amount of subsidies provided. Furthermore, as many countries have come to recognize the economic effects of the film industry and the importance of globalization, they have established subsidy regimes for international co-production and/or tax reliefs for production expenditure to attract international film producers and promote their film industries through globalization. This approach has been believed to be an effective way to support the local film industry and national economy, as well as the broader goal of global cultural diversity (UNESCO).

In particular, as trade barriers or restrictions such as import quotas and screen quotas have appeared to discriminate against foreign films vis-à-vis local films, co-production has evolved from the domestic scene to an international one. This regime is designed to grant "national treatment" to coproduced films among the different signatories. Thus it is an effective way to avoid such discrimination (Parc and Messerlin, "In Search of an Effective Trade Policy"). In theory, this provision asks them to share half the burden of film production, such as funds, actors, and staff. However, the film's location and director are treated as exceptions due to their unique characteristics. 


\section{Overseas Expansion under the International Co-production}

When cultural contents are produced, their target audience is primarily local. Hence, a deep understanding of the domestic environment is crucial. In this regard, speaking (or language), natural gestures, and cultural expressiveness are the basis for being a good actor. These do not constitute such a large burden for local actors in general, but they can be for those from other countries. As such, collaborating with international film producers or working in another country as an actor can be an extremely challenging endeavor. For this reason, many audiences will be highly appreciative of actors who expand their geographical scope to other countries. Since the Hollywood film industry has enjoyed its global dominance throughout the twentieth century, a number of international actors have wanted to pursue their careers there, such as Sophia Loren, Bruce Lee, Antonio Banderas, Roberto Benigni, and Javier Bardem. Increasingly, a variety of actors have also worked with international film producers outside of Hollywood.

An actor's overseas expansion is often well appreciated in both France and Korea despite the fact that neither is an Anglophone country. The reason behind this is that both France and Korea recognize the language barrier as a challenge that actors should overcome. Despite this language barrier, in fact, some Korean actors have recently collaborated more with Hollywood producers. For example, Lee Byunghun appeared in the movie series of G.I. Joe (2009, 2013), Red 2 (2013), Terminator Genisys (2015), Misconduct (2016), and The Magnificent Seven (2016). Bae Doona became the favored actress for the Wachowskis and had an important role in Cloud Atlas (2012) and Jupiter Ascending (2015). Furthermore, she is currently working with Netflix for a number of drama series. There are also other actors engaged in various film projects with international producers from China and Japan. While they may not be as prestigious, they do help to increase the performance fee.

Overseas expansion among actors is a phenomenon that is not limited to Korea. The history of French actors having collaborated with the Hollywood film industry is also noteworthy and more extensive than the same kind of history in Korea. For example, Juliette Binoche has been involved in various Hollywood projects such as The English Patient (1996), Chocolat (2000), Godzilla (2014), and Ghost in the Shell (2017). Vincent Cassel has appeared in Ocean's Twelve (2004), Ocean's Thirteen (2007), and Black Swan (2010). Additionally, several French actors have also collaborated with other European film producers such as in Belgium, Germany, Italy, and Spain. However, it is noteworthy to emphasize again that French actors, in general, receive a much lower performance fee outside of France according to Maraval. 
When this phenomenon is compared between France and Korea, French actors seem to be more actively engaged and have a longer tradition. In order to explain this difference, some would argue that France is in the European Union and has a cultural proximity with its neighbors. Furthermore, when France is compared with Korea, the cultural and linguistic distance among France, the United States, and other European countries is closer. There is also the added factor that Hollywood studios have been operating their European subsidiaries since the 1940s (Gubak). This may seem a compelling argument, but this trend requires a deeper analysis, instead of simply highlighting the abovementioned facts. One interesting point is that although there was this long tradition in France, the number of actors have been few in the early years, and have only started to increase recently.

In France, the increasing number of actors' overseas expansion is in fact also related to international co-production as the country has become a "favorite" for this among filmmakers due to "soft money" (Keslassy). As mentioned before, this requires equal participation in all production factors. Hence, in order for a film to be treated as a domestic production throughout the process and to benefit from the subsidies and tax-reliefs as coproduced films, it requires a certain number of actors from each counterpart country. This explains the larger number of French actors who have collaborated with international film producers when compared with Korea. This analysis can be supported further when the ratio and number of coproduced films are compared. For example, France released 258 films in 2014, but 106 of them (41.1 percent), were coproduced, whereas Korea produced only one film with Hungary as a co-production effort out of the 217 films released during the same period (UNESCO Institute for Statistics; KFC "2014 Annual Report”). In 2015, France had 142 coproduced films out of 300 films (47.3 percent) while Korea had no coproduced films among its 232 releases (UNESCO Institute for Statistics; KFC "2015 Annual Report"). It is noteworthy that most coproduced films are produced with US counterparts and/or European partners that are in fact American subsidiaries or have a tight relationship with Hollywood studios.

As evident here, the number of coproduced French films has increased, as the amount of subsidies has significantly grown. As a result, a growing number of French actors have been able to collaborate with international film producers. Of course, there is no doubt that these international film producers prefer to recruit good actors, but it is also possible to simply increase the number of French actors in order to take advantage of the French subsidies. If this case is compared with Korea where there is an increase in the number of actors who collaborate with international film producers despite few or no coproduced films, the interpretation on the overseas expansion can differ. In addition, more recently several countries have offered funds to international film producers which results in an actor from the investing country being able to appear in the film as a reward. For the actor, it 
can be a good opportunity for their career, but then we have to rethink how many of them take advantage of it to be globally competitive actors. Finally, one should not overlook the fact that these funds are usually sourced from tax payers.

\section{CONCLUSION}

As an actor, a director, and a scholar in film studies, we strongly agree that films carry a strong cultural value which is very important for a nation and its identity. This is why a number of people advocate for the increase in the level of subsidies to the film industry in order to protect and promote it. Yet, these approaches have not undertaken a deeper analysis of its impact. As our analysis shows, however, this impact needs to be carefully examined by using various quantitative and qualitative sources, coupled with real-world experiences which is often lacking in studies on this topic. For this reason, we have chosen to analyze the impact of subsidies on the performance of actors. We believe this will be helpful toward expanding the scope of research. While describing the impact of subsidies on the director-actor positional relationship, performance fee, and overseas expansion, we seek to avoid jumping to conclusions on whether these impacts are positive or negative to the film industry. Instead, we would like to add one more dimension regarding its impact on actors' performance. In addition, we raise several other questions on the need to reconsider the impact of subsidies.

There are many similarities and dissimilarities between the French and Korean film industries explicitly and inexplicitly, but this situation has evolved out of different factors. Only when we have interpreted properly and rigorously the impact and reasons behind them, can meaningful implications be drawn. Due to the abundant amount of subsidies available, the director-actor has emerged in great numbers to take advantage of this situation. This has been particularly notable in the French film industry, but remains rare in Korea. The concurrent position of director-actor is to increase the share of subsidies that directors can take. The high level of subsidies has also excelled to increase the performance fee of French actors in France. Lastly, the overseas expansion of actors has been facilitated by international co-production which is also supported by subsidies. Again, the case of the French film industry explicitly demonstrates this.

The Korean film industry provides the opposite story. In order to survive, Korean actors had to increase their workload and develop their acting performances further. In this competitive environment, actors did not distinguish between television or film work; thus, they performed for whichever production would bring in higher remuneration. As the market has further opened in Korea, competition has become 
more severe. By enhancing their acting talent, several stars have been able to go to China, Japan, and even Hollywood. Overall, this unprotected market has helped the industry to boom. The comparison presented in this paper sheds light on a need for rigorous film policies which can affect positively the development of the film industry as a whole. 


\section{Acknowledgement}

This work was supported by the Laboratory Program for Korean Studies through the Ministry of Education of the Republic of Korea and the Korean Studies Promotion Service of the Academy of Korean Studies (AKS-2015-LAB-2250003). Our gratitude goes to Patrick Messerlin for very useful discussions and comments on earlier drafts. 


\section{Notes}

1. This part relies heavily on Messerlin, Messerlin and Parc ("The Effect of Screen Quotas," “The Real Impact of Subsidies”) and Messerlin and Vanderschelden.

2. Through the Blum-Byrnes Agreements, France was able to clear its debt with the United States and obtained new credit in exchange for opening its market to American films. Due to these agreements, the French government eliminated the import quotas and adopted screen quotas; 4 weeks out of 13 weeks for French films, that is, 31 percent of the year. In 1948, the National Assembly of France modified; 5 weeks out of 13 weeks, thus 38 percent of the year.

3. This part is based on Parc ("Evaluating the Effects," "L'Impact du Quota de Diffusion," "The Effects of Protection") and Messerlin and Parc ("The Effect of Screen Quotas," “The Real Impact of Subsidies”). 


\section{Works Cited}

Bergfelder, Tim. "National, Transnational or Supranational Cinema? Rethinking European Film Studies." Media, Culture \& Society, vol. 27, no. 3, 2005, pp. 315-331.

Capital. "Cinéma : Les Acteurs Les Plus Arrosés Par Les Subventions [Film: The Most Subsidized Actors by Grants]." Capital, 12 May 2015, www.capital.fr/economiepolitique/cinema-les-acteurs-les-plus-arroses-par-les-subventions-1038205. Accessed 27 Mar. 2018.

Cocq, Emmanuel. "L'analyse Economique de la Politique Cinematographique Francaise." Ph.D. Dissertation, Sciences Po Paris, 2000.

Gubak, Thomas. "Film as International Business." Journal of Communication, vol. 24, no. 1, 1974, pp. 90-101.

Hayward, Susan. French National Cinema. 2nd ed. Routledge, 2005.

Kim, Kyuchan. "The Characteristics and Achievements of Korean Government's Content Industry Policy: A Longitudinal Study on the Cultural Budget between 1974 and 2011." [in Korean]. Journal of Communication Research, vol. 50, no. 1, 2013, pp. 276-308.

Keslassy, Elsa. "France: Filmmakers Favor Co-production Route." Variety, 18 May 2012, variety.com/2012/film/awards/france-filmmakers-favor-co-productionroute-1118053889/. Accessed 21 Oct. 2018.

KFC (Korean Film Council). 2014. Annual Report. Sanzinibook, 2015.

--. 2015 Annual Report. Sanzinibook, 2016.

Kornai, Jason. "The Soft Budget Constraint." Kyklos, vol. 39, 1986, pp. 3-30.

"Leni Riefenstahl." The Telegraph, 1o Sept. 2003, www.telegraph.co.uk/news/ obituaries/1440991/Leni-Riefenstahl.html?pageNum=3. Accessed 2 May 2018.

Maraval, Vincent. "Les Acteurs Français Sont Trop Payés! [French Actors Are Paid Too Much!]". Le Monde, 28 Dec. 2012, www.lemonde.fr/a-la-une/article/2012/12/28/lesacteurs-francais-sont-trop-payes_1811151_3208.html. Accessed 3 May 2018.

McLaughlin, Robert, and George Black. "The Introductory Course in Acting and Directing: A New Approach." Educational Theatre Journal, vol. 25, no. 4, 1973, pp. 468-473.

Messerlin, Patrick. "La politique audiovisuelle française: A bout de souffle [The French Audiovisual Policies: Breathless].” Groupe d'Economie Mondiale, gem.sciences-po.fr/ content/publications/pdf/audiovisual/Messerlin_FrenchAudiovisualPolicyo92014_ FR.pdf. 2016.

Messerlin, Patrick, and Emmanuel Cocq. "Preparing Negotiations in Service: EC Audiovisuals in the Doha Round." The Audiovisual Services Sector in the GATS Negotiations, edited by Patrick Messerlin, Stephen Siwek, and Emmanuel Cocq, AEI Studies on Services Trade Negotiations, American Enterprise Institute, 2004, pp. 32-53.

Messerlin, Patrick, and Jimmyn Parc. "The Effect of Screen Quotas and Subsidy Regime on Cultural Industry: A Case Study of French and Korean Film Industry." Journal of International Business and Economy, vol. 15, no. 2, 2014, pp. 57-73. 
Messerlin, Patrick, and Jimmyn Parc. "The Real Impact of Subsidies on the Film Industry (1970s-Present): Lessons from France and Korea." Pacific Affairs, vol. 90, no. 1, 2017, pp. $51-75$.

Messerlin, Patrick, and Isabelle Vanderschelden. "France's Protected and Subsidised Film Industry: Is the Subsidy Scheme Living Up to Its Promises?" Handbook of State Aid for Film, edited by Paul Murschetz, Roland Teichmann, and Matthias Karmasin, Springer, 2018, pp. 311-332.

MPAA (Motion Picture Association of America). Trade Barrier to Exports of US Filmed Entertainment 1995 Report to the US Trade Representative. MPAA, 1995.

Pager, Sean. "Beyond Culture vs. Commerce: Decentralizing Cultural Protection to Promote Diversity Through Trade." Northwestern Journal of International Law $\mathcal{E}$ Business, vol. 31, 2011, pp. 63-135.

Parc, Jimmyn. "Evaluating the Effects of Protectionism on the Film Industry: A Case Study Analysis of Korea." Handbook of State Aid for Film, edited by Paul Murschetz, Roland Teichmann, and Matthias Karmasin, Springer, 2018, pp. 349-366.

-.. "L'Impact du Quota de Diffusion sur l'Industrie Cinématographique Coréenne [The Impact of Screen Quotas on the Korean Film Industry]." Korea Analysis, vol. 6, 2015, pp. $37-43$.

--. "The Effects of Protection in Cultural Industries: The Case of the Korean Film Policies." The International Journal of Cultural Policy, vol. 23, no. 5, 2017, pp. 618-633.

--. "Understanding Film Co-production Strategies: A Value Chain Approach." Presentation at Media Industries Conference 2018: Current Debates and Future Directions, King's College, London, UK, May 20, 2018.

Parc, Jimmyn, and Patrick Messerlin. "In Search of an Effective Trade Policy for the Film Industry: Lessons from Korea." Journal of World Trade, vol. 52, no. 5, 2018, pp. 745-764.

Rentschler, Eric. The Ministry of Illusion: Nazi Cinema and Its Afterlife. Harvard UP, 2002.

Suid, Lawrence, and David Culbert, editors. Film and Propaganda in America: 1945 and After, volume 4. Greenwood Publishing Group, 1991.

Tannenwald, Robert. "State Film Subsidies: Not Much Bang for too Many Bucks." Center on Budget and Policy Priorities, 9 Nov. 2010, www.cbpp.org/sites/default/files/atoms/ files/11-17-10sfp.pdf. Accessed 15 Aug. 2018.

UNESCO (The United Nations Educational, Scientific and Cultural Organization). Diversity and the Film Industry: An Analysis of The 2014. UIS Survey on Feature Film Statistics. UNESCO and UNESCO Institute for Statistics, 2016.

UNESCO Institute for Statistics, http://uis.unesco.org/.

Wood, Richard, and David Culbert, editors. Film and Propaganda in America: World War I, volume 1. Greenwood Publishing Group, 1990. 